Journal of Environmental Sciences (JES)

Faculty of Graduate Studies and Environmental Research, Ain Shams University

Mahmoud, et al.

\title{
ENHANCING EFFLUENT QUALITY OF WASTEWATER TREATMENT PLANTS USING ADVANCED OXIDATION PROCESS
}

\author{
Mohamed E. M. Mahmoud(1); Taha A. M. Abd El-Razek ${ }^{(2)}$; \\ Hanan S. Abd El- Rahman ${ }^{(3)}$ and Mahmoud A. Saad ${ }^{(4)}$
}

1) Post Grade, Faculty of Graduate Studies And Environmental Research, Ain Shams University 2) Faculty of Graduate Studies and Environmental Research, Ain Shams University 3) National Research Center, Egypt 4) HCWW, Holding Company for Water and Wastewater

\begin{abstract}
The critical situation about water resources in Egypt forces the state to increase its uses from non-conventional water resources (reuse of wastewater and desalination). Wastewater reuse represent a potential source for a round 8 Billion Cubic Meters (BCM) /year. The micropollutant and the sophisticated specification hinder the usage of wastewater. Advanced oxidation process represents a new potential way for improving the effluent of Waste Water Treatment Plants (WWTPs). In this work the discharge of three WWTPs (Arab-Abosaaed station located in Helwan-Cairo, El-Berka station located in El-Salam city-Cairo and Balaqs station located in Shubra El-Kheima-Cairo) were investigated and treated. The investigation illustrated that El Berka WWTP is the most vulnerable WWTP this why its effluent was used to conduct further treatment on it. The three WWTPs are appropriate for use according to Egyptian law 48/1982 and the uses quality for treated wastewater are fitted with Class D and Class C Code 501/2015 specification. Effluent from the three-treatment plant is unsuitable for uses according to Class A and B. Hydrogen peroxide, Fenton, and photo-Fenton were used as advanced oxidants to improve the effluent quality. All the oxidants used has been successfully implemented to achieve 100\% WWQI for different reuse purposes. However, the cost benefit of using hydrogen


peroxide is more favorable as it cheaper. Further comparison between the scaleup option, hydrogen peroxide is more applicable to be scaled up and moreover, it could be nationalized as a strategic industry.

Keywords: Wastewater; WWQI; Reuse; Oxidation; Fenton.

\section{INTRODUCTION}

Water represents almost three-quarters of Earth planet surface. Most of this water is saltwater (Abd Ellah, 2020). Less than 3 percent of this water is freshwater, and most of it exists in the form of ice and snow in polar glaciers (Gleick, 1993). However, Bengtsson, (2010) and Koutsoyiannis, (2011) reported that the distribution of global water and the quantity of earth's freshwater available is depending on the global water cycle (Schuol, et al. 2008). (Sircoulon, 1991) summarized this fact, stating that there is an increasing awareness of the significant relationship between climate, water (lakes and rivers), and environment.

As many catchment areas are often focal points in terms of environmental and conservation issues, they have been shown to be good proxy indicators of local, regional, and global climatic change (Benveniste and Berry, 2004). The Intergovernmental Panel on Climate Change's (IPCC, 2007) predictions indicated that over the next decades, the increased water stress will be affecting between 75 and 250 million people due to the climate change. The same report states that the developing countries, including African countries, are the most at risk of being severely affected by climate change. 
Egypt reached the highest population in Africa of over 100 million in 2020. It has experienced rapid population growth, which leads to additional demand of water due to its limited water resources. It is predicted that Egypt's total population will be about 110 million by the year 2025 (Ferrari et al., 2014). Due to the high population and geographic location of Egypt, there is an increasing demand for water and decreasing per capita water share. Since 1990s, Egypt already has one of the lowest per capita water shares in the world. The per capita share already under the poverty line, in 2015, annual per capita consumption of renewed fresh water was $650 \mathrm{~m} 3$, which is significantly below the $1,000 \mathrm{~m} 3 /$ year water scarcity threshold. Indeed, the Nile River provides the country with some $93 \%$ of its water requirements. The total amount of deep groundwater has been estimated at about 40,000 BCM (MWRI, 2014) (Fig 1).

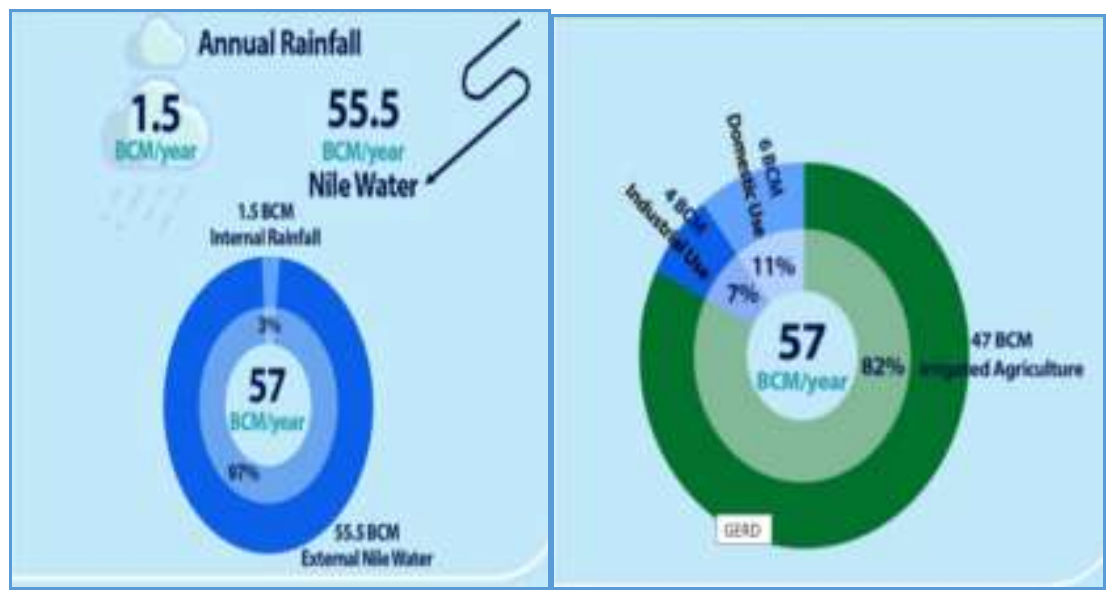

Figure(1): Water resources and demand in Egypt ( AbuZeid, 2020). 
Journal of Environmental Sciences (JES)

Faculty of Graduate Studies and Environmental Research, Ain Shams University

Mahmoud,, et al.

The critical situation about water resources in Egypt forces the state to increase its uses from non-conventional water resources (reuse of wastewater and desalination). These resources represent $22.2 \%$ of the total available water resources. The production of desalination is calculated to be $0.5 \mathrm{BCM}$ per year, according to the same strategy the amount of produced desalinated water will reach $1 \mathrm{BCM}$ by year 2030 . The fact that the available water resources in Egypt are very limited, the gap between the available water resources and the demand between reaches 15 billion cubic meters forced the state to develop the National Water Strategy.

Due to limited water resources, Egypt government has adapted a new strategy aligned with Sustainable Development Goals (SDGs) to expand its production from alternative water resources, i.e. desalination due to the fact of the high demand and very limited water resources also, according to this strategy, Egypt intend to cover $100 \%$ of population with wastewater treatment current cover is estimated to $56 \%$, reuse of the treated wastewater is included in this strategy to reuse $100 \%$ of this treated wastewater (Cheremisinoff, 2019).

The usual method of municipal or industrial waste effluents treatment processes contained with large amount of sludge having various organic and inorganic compounds occurred, pose danger for safety aspects and quality related to environmental concerns (Harrison et al, 2006). Further, the usual sludge handling processes, thickening, drying, digestion, and lime 
stabilization contribute to the on-site odors, became a severe environmental burden. (Theodore, 2009).

Studies have shown that the use of advanced oxidation processes (AOP's) yields tremendous results in removing pollutants and eliminating pathogens in wastewater treatment processes. The use of hydrogen peroxide with ultraviolet rays, where the process of combining ozone with hydrogen peroxide works to generate these oxidative radicals (OH-) The process is called Peroxonation (Zaviska et al. 2009). This study aims at investigating the possible improvement of the wastewater treatment plants effluent quality using advanced oxidation process to be more valuable for reuse.

\section{METHODOLOGY}

Based on the objectives of the study, the methodology encompassed 3 phases as follows:

- Phase 1: Allocation of the most vulnerable sanitation system through monitoring of WWTPs 2020, and Wastewater Quality Index (WWQI) will be used as a tool to accomplish the quality comparison.

- Phase 2: Determination of the effectiveness of using different oxidants (Hydrogen peroxide - Fenton - photo Fenton).

- Phase 3: Comprehensive comparison of the different techniques and recommendations. 
Journal of Environmental Sciences (JES)

Faculty of Graduate Studies and Environmental Research, Ain Shams University

Mahmoud,, et al.

- Phase I: Allocation of the most vulnerable sanitation system: A survey was done to assets the quality of effluent from 3 wastewater treatment plants (Arab-Abosaaed - Balaqs - El-Berka). Information about these three treatments is provided in table (1). 
Table(1): Typical information about the monitored Wastewater Treatment Plants (WWTPs)

\begin{tabular}{|c|c|c|c|}
\hline $\begin{array}{c}\text { Wastewater treatment } \\
\text { plant }\end{array}$ & $\begin{array}{c}\text { Arab- } \\
\text { Abosaaed }\end{array}$ & Balaqs & El-Berka \\
\hline \hline Place & $\begin{array}{c}\text { Helwan, } \\
\text { Cairo }\end{array}$ & $\begin{array}{c}\text { Shubra El- Kheima, } \\
\text { Cairo }\end{array}$ & $\begin{array}{c}\text { El-Salam City, } \\
\text { Cairo }\end{array}$ \\
\hline $\begin{array}{c}\text { Number of served residence } \\
\text { (Million) }\end{array}$ & 2.4 & 1.7 & 2.01 \\
\hline $\begin{array}{c}\text { Amount of treated } \\
\text { wastewater (m3/day) }\end{array}$ & 600,000 & 400,000 & 450,000 \\
\hline Location of discharge point & $\begin{array}{c}\text { El-Saff } \\
\text { Drain }\end{array}$ & $\begin{array}{c}\text { Shibin El Kanater } \\
\text { Drain }\end{array}$ & $\begin{array}{c}\text { Al-Gabal Al-Asfar } \\
\text { Drain }\end{array}$ \\
\hline Type of treatment train & \multicolumn{2}{|c|}{ Secondary Conventional Biological treatment } \\
\hline \hline
\end{tabular}

Samples were taken from these treatment plants for the inlet and outlet as well. Analysis for BOD, COD, TSS, TOC, and Total coliform was done according to Standard Method for Water and Wastewater 2017(Rice E.W.et al. 2017) The samples were analyzed at the reference laboratory for the wastewater (Accredited ISO 17025). All the chemicals used in analytical grades. The sampling period covers the year 2020. WWQI was used as a statical tool to allocate the most vulnerable site. WWQI was calculated based on the CCME-2001 Method (Bilgin, 2018).

\section{This method depends on the calculation of three factors:}

- Scope: (related to the number of incompliance parameters to all the number of analyzed parameters)

- Frequency (related to the repetition of non-compliance with time)

- Amplitude (related to how far the results of noncompliance from the standard) as the following:

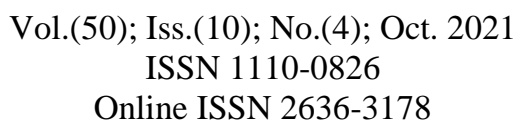


(a) The measure for scope is (F1): This represents the extent of water quality guideline non-compliance over the time period of interest.

$\mathrm{F}_{1}=\quad \frac{\text { Number of Failed Variables }}{\text { Total Number of Variables }}: 100$

(b) The measure for frequency is (F2): This represents the percentage of individual tests that do not meet objectives ("failed tests").

$\mathrm{F}_{2}=\frac{\text { Number of Failed Tests }}{\text { Total Number of Tests }}: 100$

(c) The measure for amplitude is F3: This represents the amount by which failed test values do not meet their objectives. This is calculated in three steps:

$\mathrm{F}_{3}=\frac{\mathrm{nse}}{0.01 \text { nse }+0.01}$

The WWQI is then calculated as:

$\mathrm{WQI}=100-\left(\frac{\sqrt{F 1^{2}+F 2^{2}+F 3^{2}}}{1.732}\right)$

Once the CCME WQI value has been determined, then The WQI values are converted into rankings by using the categorization scheme presented in Table (2) to express the water quality. 
Mahmoud, et al.

Table (2): WWQI ranks and color code representation.

\begin{tabular}{|c|c|c|c|}
\hline $\begin{array}{c}\text { Meaning } \\
\end{array}$ & Percent & Grade & Color code \\
\hline $\begin{array}{l}\text { Water quality is protected with the virtual } \\
\text { absence of threat or impairment; conditions very } \\
\text { close to natural or pristine levels }\end{array}$ & $94-100 \%$ & Excellent & \\
\hline $\begin{array}{c}\text { Water quality is protected with an only a minor } \\
\text { degree of threat or important; conditions rarely } \\
\text { depart from natural or desirable levels }\end{array}$ & $79-94 \%$ & Good & \\
\hline $\begin{array}{c}\text { Water quality is usually protected but } \\
\text { occasionally threatened or impaired; conditions } \\
\text { sometimes depart from natural or desirable levels }\end{array}$ & $64-79 \%$ & Marginal & \\
\hline $\begin{array}{c}\text { Water quality is frequently threatened or } \\
\text { impaired; conditions often depart from natural or } \\
\text { desirable levels }\end{array}$ & $44-64 \%$ & Fair & \\
\hline $\begin{array}{c}\text { Water quality is almost always threatened or } \\
\text { impaired; conditions usually depart from natural } \\
\text { or desirable levels }\end{array}$ & $0-44 \%$ & poor & \\
\hline
\end{tabular}

WWQI: WasteWater Quality Index

After selection of the most vulnerable WTTP. Different AOPs used to improve the effluent of the selected vulnerable WWTP. The treatment removal percent will be calculated, and a comparison will be done to investigate the applicability of each. The optimum condition for each oxidant will be also specified.

The following statistical equation has been used for the calculation of removals percent

Removal percent $=\frac{\text { conc, befortreatment-Conc, after treatment }}{\text { Conc, befortreatment }} \leqslant 100$

The limits used for the comparison and to identify the efficiency of the treatment are the national standard. Egyptian code for reuse of treated 
Journal of Environmental Sciences (JES)

Faculty of Graduate Studies and Environmental Research, Ain Shams University

Mahmoud, et al.

wastewater in agriculture (Code 501/2015) and according to the specification of Egyptian law 48/1982.

Phase II: Determination of the effectiveness of different oxidants:

Different oxidants were used to enhance the quality of the effluent via oxidation and/or coagulation the following oxidant were used:

- Hydrogen peroxide Treatment: Jar test was used as apparatus to conduct the treatment process. Samples were collected from the effluent of ElBerka WTTP. Baseline parameters were measured to determine the removal percentage after treatment. Hydrogen peroxide purchased from Aldrich (50\%) was used to inject the effluent by different doses $(5,10$, 15, 20, 25 and $30 \mathrm{mg} / \mathrm{l})$. Different contact time and stirring rate were also tested to determine the optimum condition.

- Fenton treatment: the effluent of El Berka was injected by hydrogen peroxide $(15 \mathrm{mg} / \mathrm{l})$, and the stirring was adjusted at $20 \mathrm{RPM}$ for $30 \mathrm{~min}$ with no $\mathrm{pH}$ correction. ferrous sulfate was added by different doses 5,10 , 15 , and $20 \mathrm{mg} / \mathrm{l}$. then the water was tested for the different quality parameters to determine the removal efficiency.

- Photo-Fenton: UV lamp was purchased from local provider with wavelength $189 \mathrm{~nm}$ and power of 6 watt, the sample was collected from the effluent of El Berka WWTP and treated according to the optimum conditions results from the conducted experiment. 


\section{Phase III: Comprehensive comparison of the different techniques and} recommendations: Based on the results achieved and the economic value of each oxidant together with its technical feasibility, the comparison will allow the best selection. Different factors have been studied to determine the best oxidants.

\section{RESULTS AND DISCUSSION}

1. Monitoring of WWTPs: The following table represents the results of survey all over the year 2020. Samples were taken from inlet and outlet of the three WWTPs. 
Journal of Environmental Sciences (JES)

Faculty of Graduate Studies and Environmental Research, Ain Shams University

Mahmoud, et al.

Table(3): Results of input and output of Arab-Abosaaed

\begin{tabular}{|c|c|c|c|c|c|c|}
\hline Month & Location & TSS mg/l & $\begin{array}{c}\text { BOD5 } \\
\mathrm{mg} / \mathrm{l}\end{array}$ & COD mg/l & TOC mg/l & $\begin{array}{c}\mathrm{TC} \\
\mathrm{CFU} / 100 \mathrm{ml}\end{array}$ \\
\hline \multirow{2}{*}{ Jan. } & Input & 188 & 168 & 411 & 154 & $88 * 107$ \\
\hline & Output & 18 & 21 & 62 & 24 & 6500 \\
\hline \multirow{2}{*}{ Feb. } & Input & 211 & 205 & 417 & 159 & $63 * 107$ \\
\hline & Output & 23 & 22 & 65 & 24 & 5400 \\
\hline \multirow{2}{*}{ Mar. } & Input & 303 & 277 & 512 & 197 & $65 * 107$ \\
\hline & Output & 26 & 24 & 67 & 25 & 6500 \\
\hline \multirow{2}{*}{ Apr } & Input & 197 & 188 & 490 & 178 & $65 * 107$ \\
\hline & Output & 22 & 21 & 58 & 22 & 6700 \\
\hline \multirow{2}{*}{ May. } & Input & 213 & 197 & 505 & 192 & $71 * 107$ \\
\hline & Output & 26 & 23 & 59 & 22 & 7100 \\
\hline \multirow{2}{*}{ Jun. } & Input & 276 & 245 & 566 & 213 & $61 * 107$ \\
\hline & Output & 33 & 27 & 74 & 28 & 5400 \\
\hline \multirow{2}{*}{ Jul. } & Input & 178 & 158 & 404 & 152 & $45 * 107$ \\
\hline & Output & 16 & 18 & 53 & 20 & 5200 \\
\hline \multirow{2}{*}{ Aug. } & Input & 199 & 179 & 449 & 173 & $64 * 107$ \\
\hline & Output & 21 & 18 & 61 & 26 & 5600 \\
\hline \multirow{2}{*}{ Sep. } & Input & 218 & 205 & 437 & 169 & $68 * 107$ \\
\hline & Output & 28 & 25 & 66 & 26 & 5500 \\
\hline \multirow{2}{*}{ Oct. } & Input & 202 & 189 & 398 & 151 & $65 * 107$ \\
\hline & Output & 23 & 25 & 64 & 27 & 4800 \\
\hline \multirow{2}{*}{ Nov. } & Input & 214 & 198 & 423 & 161 & $88 * 107$ \\
\hline & Output & 24 & 27 & 68 & 29 & 6500 \\
\hline \multirow{2}{*}{ Dec. } & Input & 212 & 199 & 443 & 171 & $71 * 107$ \\
\hline & Output & 23 & 25 & 71 & 28 & 7600 \\
\hline
\end{tabular}

TSS: Total Suspended Solids, $\mathrm{BOD}_{5}$ : Biochemical Oxygen Demand, COD:

Chemical Oxygen Demand, TOC: Total Organic Carbon, TC: Total Coliform 
Journal of Environmental Sciences (JES)

Faculty of Graduate Studies and Environmental Research, Ain Shams University

Mahmoud, et al.

Table(4): Results of input and output of El-Berka

\begin{tabular}{|c|c|c|c|c|c|c|}
\hline Month & Location & $\begin{array}{l}\text { TSS } \\
\text { mg/l }\end{array}$ & $\begin{array}{c}\text { BOD5 } \\
\text { mg/l }\end{array}$ & $\begin{array}{c}\text { COD } \\
\mathrm{mg} / \mathrm{l}\end{array}$ & TOC mg/l & TC CFU/100ml \\
\hline \multirow{2}{*}{ Jan. } & Input & 330 & 288 & 611 & 231 & $65 * 107$ \\
\hline & Output & 41 & 34 & 77 & 31 & 14200 \\
\hline \multirow{2}{*}{ Feb. } & Input & 343 & 317 & 698 & 259 & $78 * 107$ \\
\hline & Output & 39 & 34 & 73 & 27 & 9400 \\
\hline \multirow{2}{*}{ Mar. } & Input & 377 & 354 & 688 & 256 & $67 * 107$ \\
\hline & Output & 43 & 35 & 77 & 29 & 12300 \\
\hline \multirow{2}{*}{ Apr } & Input & 345 & 307 & 634 & 240 & $75 * 107$ \\
\hline & Output & 45 & 36 & 78 & 29 & 8900 \\
\hline \multirow{2}{*}{ May. } & Input & 355 & 311 & 602 & 233 & $56 * 107$ \\
\hline & Output & 37 & 32 & 73 & 27 & 8700 \\
\hline \multirow{2}{*}{ Jun. } & Input & 431 & 379 & 711 & 277 & $78 * 107$ \\
\hline & Output & 38 & 23 & 69 & 29 & 8890 \\
\hline \multirow{2}{*}{ Jul. } & Input & 388 & 367 & 645 & 244 & $63 * 107$ \\
\hline & Output & 43 & 35 & 88 & 31 & 12000 \\
\hline \multirow{2}{*}{ Aug. } & Input & 331 & 301 & 677 & 244 & $45 * 107$ \\
\hline & Output & 44 & 37 & 78 & 29 & 7760 \\
\hline \multirow{2}{*}{ Sep. } & Input & 310 & 277 & 644 & 240 & $67 * 107$ \\
\hline & Output & 36 & 30 & 71 & 34 & 6700 \\
\hline \multirow{2}{*}{ Oct. } & Input & 430 & 389 & 755 & 288 & $64 * 107$ \\
\hline & Output & 46 & 41 & 75 & 31 & 10900 \\
\hline \multirow{2}{*}{ Nov. } & Input & 338 & 322 & 678 & 266 & $83 * 108$ \\
\hline & Output & 45 & 41 & 78 & 29 & 7600 \\
\hline \multirow{2}{*}{ Dec. } & Input & 333 & 289 & 711 & 277 & $75 * 107$ \\
\hline & Output & 43 & 37 & 75 & 28 & 7700 \\
\hline
\end{tabular}

TSS: Total Suspended Solids, BOD 5 : Biochemical Oxygen Demand, COD:

Chemical Oxygen Demand, TOC: Total Organic Carbon, TC: Total Coliform 
Journal of Environmental Sciences (JES)

Faculty of Graduate Studies and Environmental Research, Ain Shams University

Mahmoud, et al.

Table(5): Results of input and output of Balaqs

\begin{tabular}{|c|c|c|c|c|c|c|}
\hline Month & Location & $\begin{array}{c}\text { TSS } \\
\text { mg/l }\end{array}$ & $\begin{array}{c}\text { BOD5 } \\
\text { mg/l }\end{array}$ & $\begin{array}{c}\mathrm{COD} \\
\mathrm{mg} / \mathrm{l}\end{array}$ & $\begin{array}{l}\text { TOC } \\
\mathrm{mg} / \mathrm{l}\end{array}$ & TC CFU/100ml \\
\hline \multirow{2}{*}{ Jan. } & Input & 220 & 189 & 455 & 171 & $43 * 107$ \\
\hline & Output & 22 & 19 & 61 & 23 & 1060 \\
\hline \multirow{2}{*}{ Feb. } & Input & 276 & 256 & 489 & 188 & $45 * 107$ \\
\hline & Output & 27 & 23 & 68 & 24 & 9450 \\
\hline \multirow{2}{*}{ Mar. } & Input & 178 & 164 & 379 & 144 & $69 * 107$ \\
\hline & Output & 17 & 14 & 53 & 19 & 7080 \\
\hline \multirow{2}{*}{ Apr } & Input & 266 & 231 & 512 & 192 & $48 * 107$ \\
\hline & Output & 31 & 27 & 69 & 27 & 9400 \\
\hline \multirow{2}{*}{ May. } & Input & 366 & 311 & 617 & 233 & $45 * 107$ \\
\hline & Output & 35 & 32 & 77 & 29 & 8750 \\
\hline \multirow{2}{*}{ Jun. } & Input & 230 & 211 & 544 & 204 & $61 * 107$ \\
\hline & Output & 31 & 23 & 69 & 26 & 6700 \\
\hline \multirow{2}{*}{ Jul. } & Input & 188 & 172 & 388 & 147 & $41 * 107$ \\
\hline & Output & 22 & 19 & 61 & 23 & 5800 \\
\hline \multirow{2}{*}{ Aug. } & Input & 200 & 181 & 407 & 153 & $45 * 107$ \\
\hline & Output & 19 & 17 & 56 & 22 & 9400 \\
\hline \multirow{2}{*}{ Sep. } & Input & 310 & 277 & 644 & 240 & $35 * 107$ \\
\hline & Output & 31 & 26 & 78 & 30 & 8000 \\
\hline \multirow{2}{*}{ Oct. } & Input & 233 & 211 & 508 & 191 & $64 * 107$ \\
\hline & Output & 26 & 22 & 66 & 25 & 10900 \\
\hline \multirow{2}{*}{ Nov. } & Input & 190 & 177 & 432 & 162 & $33 * 107$ \\
\hline & Output & 24 & 22 & 63 & 24 & 7600 \\
\hline \multirow{2}{*}{ Dec. } & Input & 180 & 190 & 410 & 154 & $55 * 107$ \\
\hline & Output & 19 & 21 & 56 & 24 & 7700 \\
\hline
\end{tabular}

TSS: Total Suspended Solids, $\mathrm{BOD}_{5}$ : Biochemical Oxygen Demand, COD:

Chemical Oxygen Demand, TOC: Total Organic Carbon, TC: Total Coliform

To clarify the effectiveness of different WTTPs the removal percent of the different WWTP have been determined. The percent removal of TSS is ranging from $85 \%$ to $92 \%$ with the lowest removal for El-Berka and highest removal was accomplished for Arab Abosaaed. The removal percent of 
Journal of Environmental Sciences (JES)

Faculty of Graduate Studies and Environmental Research, Ain Shams University

Mahmoud, et al.

BOD ranging from $86 \%$ to $94 \%$ for Arab Abosaaed and El Berka, respectively. The removal percent for COD ranging from $83 \%$ to $90 \%$ for Arab Abosaaed and El Berka, respectively. Finally, for the removal of TOC range from $81 \%$ to $90 \% \%$ for Arab Abosaaed and El Berka, respectively. Biological treatment processes, in combination with primary sedimentation, typically remove $85 \%$ of the BOD and TSS originally present in the raw wastewater and some of the heavy metals. Activated sludge generally produces an effluent of slightly higher quality, in terms of these constituents, than biofilters or RBCs (Asano and Tchobanoglous, 1987).

2. Assessment of WWTPs:Wastewater quality index is a statistical tool used to summarize the complicated chemical, physical, and microbiological data into one single number. The number ranging from $0-100 \% .0 \%$ means that water is totally inadequate for the intended uses. $100 \%$ means that water is of excellent quality for the intended uses. Different standards were used to assess the quality according to the different uses of the treated waste. Two level of standard were used. Law $48 / 1982$ is specified for the quality for water before discharge to drains fresh water and marine water (MWRI, 2015). Code 501/2015 is specified for the reused water for different purposes (ECP 501 - 2015). The following tables explain further about decrees and specifications. 
Journal of Environmental Sciences (JES)

Faculty of Graduate Studies and Environmental Research, Ain Shams University

Mahmoud, et al.

Table(6): Grade of treatment and types of crops according to code 501/2015

\begin{tabular}{|c|c|}
\hline Standard & Scope \\
\hline \hline Law 48/1982 & Quality of discharge waste to drains \\
\hline Code 501/2015 - Class A & Group 1-1: Green landscapes in educational \\
& establishments, public and private parks \\
Group 1-2: Fruits
\end{tabular}

The water is more valuable as its quality is suitable for the different classes from A to D. The following graph represents the Wastewater Quality Index of the three Wastewater Treatment Plants 
Journal of Environmental Sciences (JES)

Faculty of Graduate Studies and Environmental Research, Ain Shams University

Mahmoud,, et al.

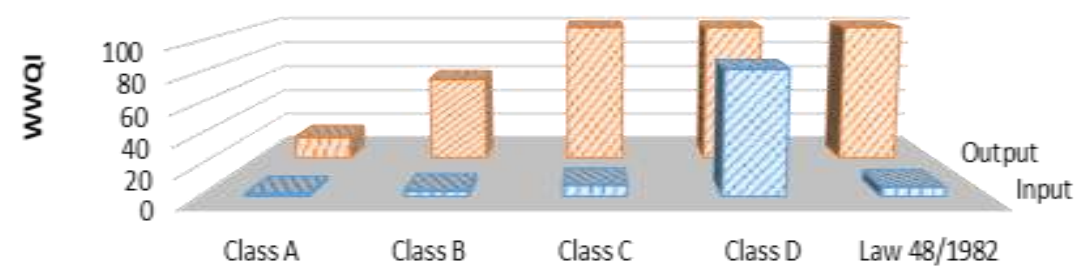

\begin{tabular}{|l|c|c|c|c|c|}
\cline { 2 - 7 } \multicolumn{1}{c|}{} & Class A & Class B & Class C & Class D & Law 48/1982 \\
\hline \$Input & 2 & 4 & 8 & 84 & 7 \\
\hline Q Output & 16 & 61 & 100 & 100 & 100 \\
\hline
\end{tabular}

Figure(2): Wastewater Quality Index for the input and output of Balaqs Wastewater Treatment Plant.

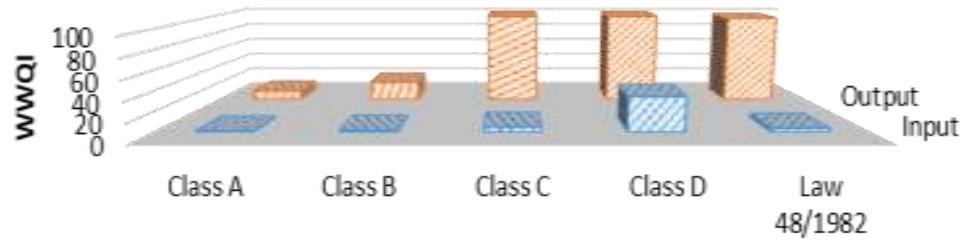

\begin{tabular}{|l|c|c|c|c|c|}
\cline { 2 - 6 } \multicolumn{1}{c|}{} & Class A & Class B & Class C & Class D & Law 48/1982 \\
\hline D Input & 1 & 3 & 5 & 36 & 5 \\
\hline D Output & 11 & 21 & 100 & 100 & 98 \\
\hline
\end{tabular}

Figure(3): Wastewater Quality Index for the input and output of El-Berka Wastewater Treatment Plant. 


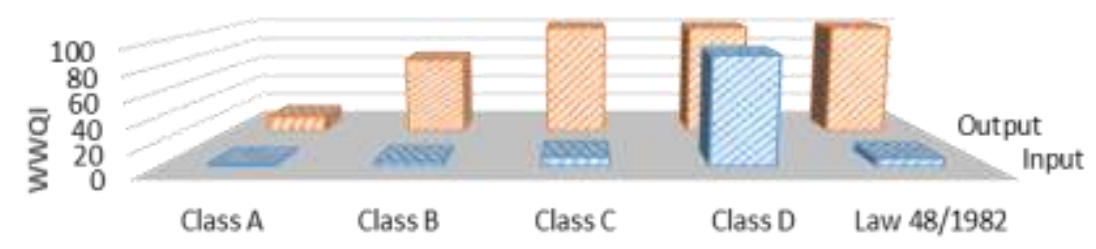

\begin{tabular}{|l|c|c|c|c|c|}
\cline { 2 - 6 } \multicolumn{1}{c|}{} & Class A & Class B & Class C & Class D & Law 48/1982 \\
\hline Einput & 2 & 4 & 8 & 91 & 7 \\
\hline DOutput & 14 & 70 & 100 & 100 & 100 \\
\hline
\end{tabular}

Figure(4): Wastewater Quality Index for the input and output of ArabAbosaaed Wastewater Treatment Plant.

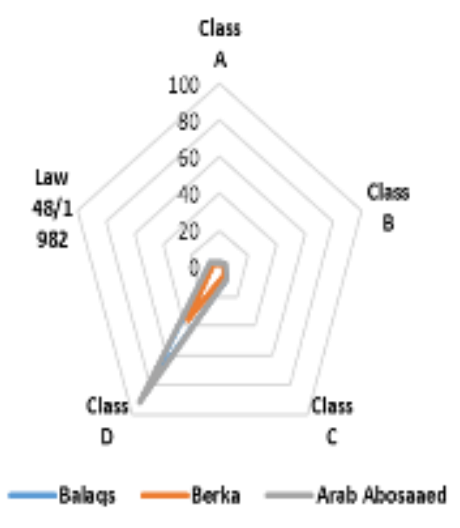

Input

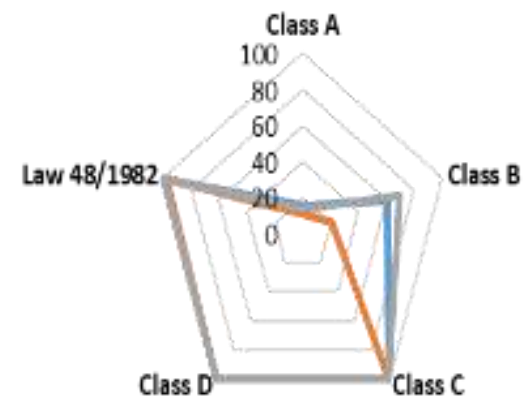

Balaqs $=$ Berka $=$ Arab Abosaaed

Figure(5): Comparison of Wastewater Quality Index for the input and output of Wastewater Treatment Plants. 
From figure 5, Raw waste with its characteristic is unsuitable for all uses. However, the class D plants according to Egyptian code for reuse could be a potential user for Balaqs and Arab-Abosaaed input water as its. Wastewater Quality Index (WWQI) for these two plants is around 90\% which categorized as excellent water for reuse for plants such as soybean rapeseed - Jojoba - and Jatropha - Castor that used as biodiesel fuel. However, El Berka shows far less quality input water, Wastewater Quality Index (WWQI) is 36 with poor quality for even class D plants. The lower quality of input water of El Berka Wastewater Treatment Plant could be explained by the presence of many industrial wastes received by the sewer network together with the unorganized time of pumping from pumping stations. For the effluent (output) of the three Wastewater Treatment Plants (WWTPs), mostly the three are appropriate for use according to law 48/1982, Class D and Class C Code 501/2015 specification. However, El Berka showed lower quality. This could be owed to bad input water quality.

Figure 5, illustrates that effluent from the three-treatment plant is unsuitable for uses according to Class A and B. This hinders the use of water in the production of higher-value agricultural goods. Any improvement of the water quality at these two categories Class A and B plants would be of high economic and social benefit. Furthermore, some of the agricultural land around the drains irrigated using the water from drains, enhancing of water quality in the outlet would for sure have a positive impact on the water quality at the drains and for the public health.

$$
\begin{gathered}
\text { Vol.(50); Iss.(10); No.(4); Oct. } 2021 \\
\text { ISSN 1110-0826 } \\
\text { Online ISSN 2636-3178 }
\end{gathered}
$$


Nicole, et al. 2006 illustrated that, the options for sustainable reuse projects are related to the quality of the effluent, and the environmental risk associated with land application for a variety of crops and activities. Patterson (2000) points at the different regulations existing for domestic and industrial effluent at an example of Australia which is valid worldwide. He describes the households as a high potential of pollution since they can discharge "a cocktail of chemicals at varying concentrations, together with biodegradable and non-biodegradable solids" without any concern as to the ramifications of those discharges either on the treatment system or the expected final quality of the discharged water. Whereas discharges from commercial and industrial premises into sewers are under greater scrutiny as government councils implement licensing and monitoring programs. As already mentioned by specifying some advantages, agriculture can be understood as a land treatment system as part of the treatment cycle and is considered as the nutrient recycling part of the loop. The soil as a bioreactor and its capacity to attenuate contaminants are taken into account. Nevertheless, quality requirements of the treated wastewater used for irrigation purposes must be met (Juanico, 1993 cited in Bahari A. 1999). According to the comparison of the three different WWTPs, El Berka was selected as the most vulnerable WWTP, to conduct the treatment experiment on it. 
3. Enhancement of El Berka Effluent using different oxidants: In this section experiment was done to determine of the effectiveness of using different oxidants (hydrogen peroxide, Fenton and photo Fenton).

- Using of hydrogen peroxide to enhance wastewater quality: 50-liter sample was collected from the effluent of El-Berka WWTP. Different conditions were tested to determine the optimum conditions. Jar test was used as apparatus to conduct the remediation experiment. The effluent water was distributed equally at 1-liter beakers, and the following conditions were studied (oxidant dose, time and Stirring rate)

A. Oxidant dose: Hydrogen peroxide was injected by different doses 5, 10, $15,20,25$, and $30 \mathrm{mg} / \mathrm{l}$ to the effluent of El Berka treatment plant. The rate of stirring was remained fixed at $40 \mathrm{rpm}$. The samples were taken after 10 min of stirring. The samples were tested for TSS, COD, BOD5, TOC and T. Coliform. The following table summarizes the results of treatment of the El Berka Effluent water via hydrogen peroxide and illustrated graphically at Figure 6. 
Journal of Environmental Sciences (JES)

Faculty of Graduate Studies and Environmental Research, Ain Shams University

Mahmoud,, et al.

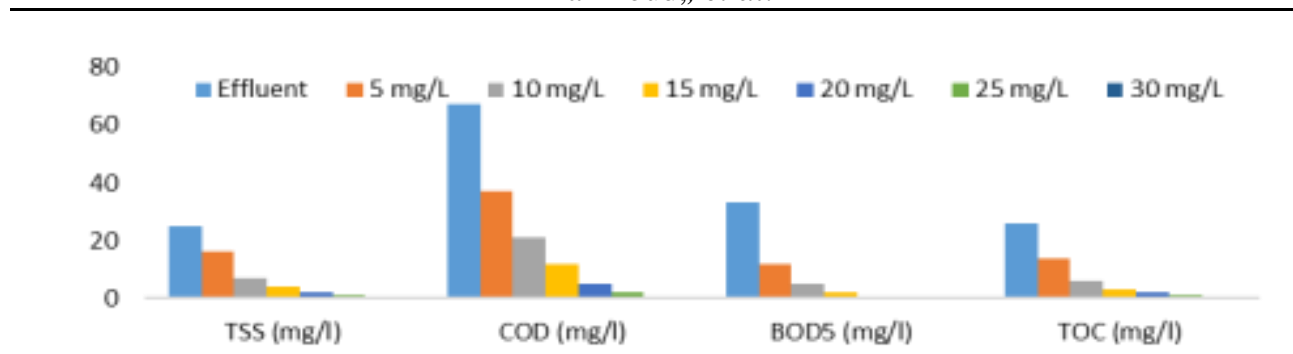

TSS: Total Suspended Solids, COD: Chemical Oxygen Demand, BOD : Biochemical Oxygen Demand, TOC: Total Organic Carbon

Figure(6): Effect of Hydrogen peroxide dose on the quality of thee effluent of El Berka treatment plant

It is clear that hydrogen peroxide by a dose of $15 \mathrm{mg} / \mathrm{l}$ is very effective in the removal of different pollutants. The removal percent of TSS, COD, BOD, TOC, and Coliform is $84 \%, 83 \%, 94 \%, 89 \%$ and $97 \%$, respectively. The effluent will be suitable for reuse for all the mentioned categories. However, the total coliform is still noncompliance with this concentration. Concentration above $15 \mathrm{mg} / \mathrm{l}$ shows significant removal of microbiological aspects.

Ksibi, 2006 stated that hydrogen peroxide has been used to reduce BOD, COD, offensive odor and foaminess in domestic or industrial wastewater for many years. While the cost to clean up these wastewaters through the chemical oxidization is typically more expensive than through the physical or biological means, hydrogen peroxide can be used as an autonomous treatment or as an improvement of existing physical or biologic 
treatment processes, according to the situation. Hydrogen peroxide can be used alone or with a catalyst such as iron (Fe2+), UV light, ozone (O3) catalytic autoxidation and the alkali contribute to the reduction of the $\mathrm{BOD} / \mathrm{COD}$ in the wastewater. The majority of organic compounds were found to be destroyed by hydrogen peroxide oxidation process, giving $85 \%$ reduction of $\mathrm{COD}$ and $\mathrm{BOD} 5 / \mathrm{COD}$. Also, He found that that the number of total coliforms exponentially decreased with increasing dose and fell to low levels at the dose of $2.5 \mathrm{ml} / \mathrm{L}$. A relatively high rate of bacterial inactivation was observed when the concentration of $\mathrm{H} 2 \mathrm{O} 2$ is equal to $2.5 \mathrm{ml} / \mathrm{L}$. The viable cell count decreased after 120 min to about $3 \log$ orders.

B. Contact time: Hydrogen peroxide was injected by a constant dose of 15 $\mathrm{mg} / \mathrm{l}$ to the effluent of El Berka treatment plant. The time of treatment was changed from $5 \mathrm{~min}$ till $60 \mathrm{~min}$. The rate of stirring was remained fixed at 40 RPM. The supernatant water is then analyzed for the different parameters. The data is mentioned in figure (7). 
Journal of Environmental Sciences (JES)

Faculty of Graduate Studies and Environmental Research, Ain Shams University

Mahmoud,, et al.

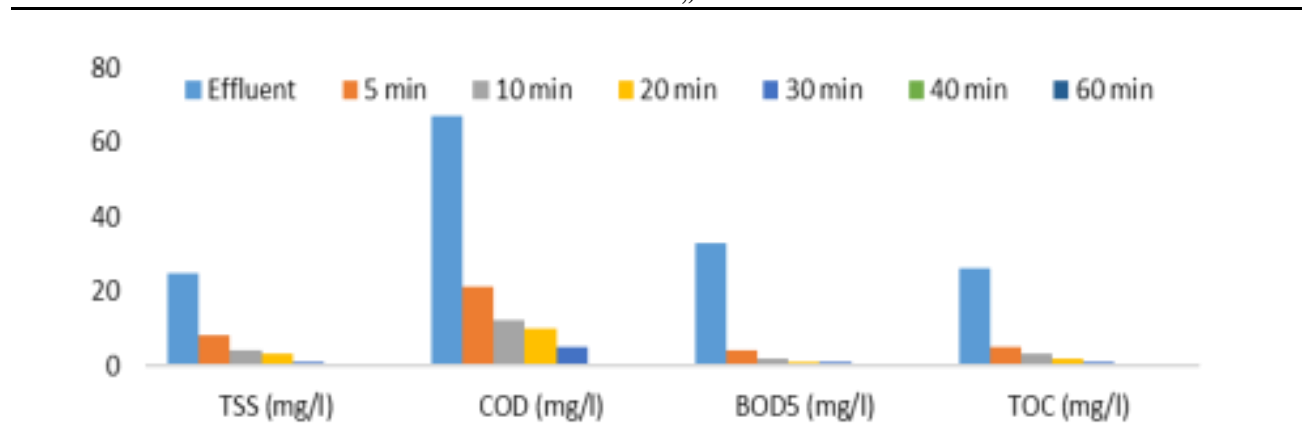

TSS: Total Suspended Solids, COD: Chemical Oxygen Demand, BOD 5 : Biochemical Oxygen Demand, TOC: Total Organic Carbon

Figure(7): Effect of time of treatment on the quality of the effluent of El Berka treatment plant

It is clear that the time increase the removal percent of different pollutant increase, the contact time at $30 \mathrm{~min}$. is very effective in the removal of different pollutants. The removal percent of TSS, COD, BOD, TOC, and Coliform is $96 \%, 93 \%, 97 \%, 96 \%$ and $100 \%$, respectively. As a rule of thumb $15 \mathrm{mg} / \mathrm{l}$ and $30 \mathrm{~min}$ mixing time is selected as optimum conditions.

Collivignarelli, et al. (2017) illustrated that, the Fenton process, while showing a moderate efficiency (25\% COD removal) in the treatment of high loaded wastewaters, provided excellent results in the treatment of aqueous wastes with high content of surfactants. An average yield removal of $70 \%$ for non-ionic surfactants (TAS) and 95\% for anionic surfactants (MBAS) 
was obtained, under the following optimal conditions: $\mathrm{Fe}_{2}+/ \mathrm{H}_{2} \mathrm{O}_{2}=1 / 4$, $\mathrm{H}_{2} \mathrm{O}_{2} /$ COD initial ratio $=1$, and contact time $=30 \mathrm{~min}$

Karimi, et al. (2017) Found that residence time, and $\mathrm{H}_{2} \mathrm{O}_{2}$ dose are the most important factors affecting the degradation of organic matter. The GAC/Fe catalyst process had a higher efficiency than other absorbents for organic matter oxidation.

c. Rate of stirring: Hydrogen peroxide was injected by a constant dose of $15 \mathrm{mg} / \mathrm{l}$ to the effluent of El Berka treatment plant. The time of treatment with adjusted to be with $30 \mathrm{~min}$. The rate of stirring was varied from no stirring to $160 \mathrm{rpm}$. The supernatant water is then analyzed for the different parameters. The data is mentioned in figure 8 .

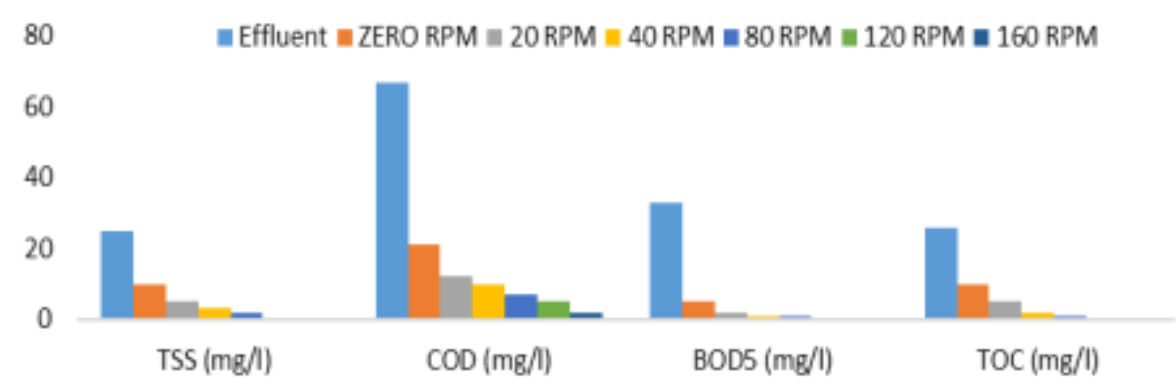

TSS: Total Suspended Solids, COD: Chemical Oxygen Demand, BOD5: Biochemical Oxygen Demand, TOC: Total Organic Carbon

Figure (8): Effect of rate of stirring on the quality of the effluent of El Berka treatment plant. 
It is clear that the stirring increases the removal percent of different pollutant increase, the stirring rate at $40 \mathrm{rpm}$ is very effective in the removal of different pollutants. The removal percent of TSS, COD, BOD, TOC, and Coliform is $88 \%, 85 \%, 97 \%, 92 \%$ and $100 \%$, respectively. After reviewing the results, the following is considered the optimum conditions for treatment via hydrogen peroxide so far:

- Dose: $15 \mathrm{mg} / \mathrm{l}$

- Stirring rate: $40 \mathrm{rpm}$

- Stirring time: $30 \mathrm{~min}$

However, the significant removal of different pollutants accompanied by the usage of hydrogen peroxide, still a margin for improving the removal efficiency and decrease the probability of formulating oxidants byproducts due to formation of free radicals.

\section{- Using of Fenton (Ferrous sulfate/hydrogen peroxide) to enhance} wastewater quality: Ameta, (2018) stated that Fenton is an effective advanced treatment process. The hydroxyl radical $(\mathrm{OH}-)$ can be generated from the reaction between aqueous ferrous ions and hydrogen peroxide $\left(\mathrm{H}_{2} \mathrm{O}_{2}\right)$, and it can destroy refractory and toxic organic pollutants in wastewater.

Jar test was used for testing the removal efficiency of Fenton, the optimum condition that was determined for hydrogen peroxide have been 
Mahmoud, et al.

taken into consideration while treating water by Fenton reagent. The data is mentioned in Table 7.

Table (7): Effect of Fenton reagent in wastewater quality

\begin{tabular}{|c|c|c|c|c|c|c|c|c|c|}
\hline $\begin{array}{c}\text { parameter } \\
\mathbf{s}\end{array}$ & $\begin{array}{c}\text { Efflue } \\
\text { nt }\end{array}$ & $\begin{array}{c}\text { Fenton } \\
5 \mathrm{mg} / \mathrm{l} \\
(\mathrm{FeSO} \\
4)+15 \\
\mathrm{mg} / \mathrm{l} \\
\mathrm{H} 2 \mathrm{O} 2\end{array}$ & $\begin{array}{c}\text { Remov } \\
\text { al } \\
\%\end{array}$ & $\begin{array}{c}\text { Fenton } \\
10 \mathrm{mg} / \mathrm{l} \\
(\mathrm{FeSO} \\
4)+15 \\
\mathrm{mg} / \mathrm{l} \\
\mathrm{H} 2 \mathrm{O} 2\end{array}$ & $\begin{array}{c}\text { Remov } \\
\text { al } \\
\%\end{array}$ & $\begin{array}{c}\text { Fenton } \\
15 \mathrm{mg} / \mathrm{l} \\
(\mathrm{FeSO} \\
4)+15 \\
\mathrm{mg} / \mathrm{l} \\
\mathrm{H} 2 \mathrm{O} 2\end{array}$ & $\begin{array}{c}\text { Remov } \\
\text { al } \\
\%\end{array}$ & $\begin{array}{c}\text { Fenton } \\
20 \mathrm{mg} / \mathrm{l} \\
(\mathrm{FeSO} \\
4)+15 \\
\mathrm{mg} / \mathrm{l} \\
\mathrm{H} 2 \mathrm{O} 2\end{array}$ & $\begin{array}{c}\text { Remov } \\
\text { al } \\
\%\end{array}$ \\
\hline TSS (mg/l) & 25 & 5 & 80 & 1 & 96 & 0 & 100 & 0 & 100 \\
\hline $\begin{array}{l}\text { COD } \\
(\mathrm{mg} / \mathrm{l})\end{array}$ & 67 & 12 & 82 & 5 & 93 & 3 & 96 & 0 & 100 \\
\hline $\begin{array}{c}\text { BOD5(mg/ } \\
\text { 1) }\end{array}$ & 33 & 3 & 91 & 0 & 100 & 0 & 100 & 0 & 100 \\
\hline $\begin{array}{c}\text { TOC } \\
(\mathrm{mg} / \mathrm{l})\end{array}$ & 26 & 3 & 88 & 1 & 96 & 0 & 100 & 0 & 100 \\
\hline $\begin{array}{c}\mathrm{TC} \\
\mathrm{CFU} / 100 \mathrm{~m} \\
1\end{array}$ & 10900 & 40 & 100 & 5 & 100 & 2 & 100 & 0 & 100 \\
\hline
\end{tabular}

TSS: Total Suspended Solids, BOD5: Biochemical Oxygen Demand,

COD:

Chemical Oxygen Demand, TOC: Total Organic Carbon, TC: Total Coliform

Table (7), clarify that Fenton is more efficient than using hydrogen peroxide alone. However, referring to the cost of ferrous sulfate and comparing the reuse codes, it could be more economically efficient to use hydrogen peroxide alone.

In order to improve the wastewater quality, advanced treatment needs the removal of refractory organics from the wastewater (Min $\mathrm{Xu}$ et. al., 2020). In recent years, Fenton has been used to treat refractory wastewater by combining it with other wastewater treatment technologies. The application of the Fenton oxidation process, as a pretreatment, oxidizes refractory organics and improves the biodegradability, solubility, and 
coagulation, which are beneficial to the subsequent treatment. It has many advantages, but drawbacks are significant such as a strong acid environment, the cost of reagents consumption, and the large production of ferric sludge, which limits Fenton's further application.

- Using of Photo-Fenton (Ferrous sulfate/hydrogen peroxide) to enhance wastewater quality: Photo-Fenton's process as one of the advanced oxidation processes is a potentially useful oxidation process in treating such wastewater. Lab-scale experiments with UV source, coupled with Fenton's reagent, showed that hydrocarbon oil is degradable through such a process. He reagent (Fe2+ and $\mathrm{H} 2 \mathrm{O} 2$ concentration) and $\mathrm{pH}$ are used as the controlling factors to be optimized. Maximal COD reduction (91.7\%) was achieved when wastewater samples were treated at $\mathrm{pH} 3.5$ in the presence of hydrogen peroxide and iron in amounts of 403.9 and $48.4 \mathrm{mg} / \mathrm{L}$, respectively, (Tony and Bedri, 2014).

$10 \mathrm{mg} / \mathrm{l}$ Ferrous sulfate $+15 \mathrm{mg} / \mathrm{l}$ hydrogen peroxide were injected to the wastewater. The sample was pumped into the UV lamp chamber to accomplish the photo-Fenton step. The water then tested for the removal efficiency of the different quality parameters. Table (8) represents the results after treatment by Photo- Fenton, the removal efficiency is $100 \%$ for all the measured parameters. 
Mahmoud, et al.

Table(8): Effect of Photo-Fenton reagent in wastewater quality

\begin{tabular}{|c|c|c|c|}
\hline parameters & Effluent & $\begin{array}{c}\text { Photo-Fenton } \\
10 \mathrm{mg} / \mathrm{l}\left(\mathrm{FeSO}_{4}\right)+15 \mathrm{mg} / \mathrm{l} \mathrm{H}_{2} \mathrm{O}_{2} \\
\end{array}$ & Removal\% \\
\hline TSS (mg/l) & 25 & 0 & 100 \\
\hline $\mathrm{COD}(\mathrm{mg} / \mathrm{l})$ & 67 & 0 & 100 \\
\hline BOD5(mg/l) & 33 & 0 & 100 \\
\hline TOC (mg/l) & 26 & 0 & 100 \\
\hline $\mathrm{TC}(\mathrm{CFU} / 100 \mathrm{ml})$ & 10900 & 0 & 100 \\
\hline
\end{tabular}

TSS: Total Suspended Solids, BOD5: Biochemical Oxygen Demand, COD:

Chemical Oxygen Demand, TOC: Total Organic Carbon, TC: Total Coliform

- Comprehensive comparison of the different technologies and recommendations: Based on the results mentioned in section 3.3., the following table concludes the optimum condition for each oxidant used and the corresponding achieved the removal of different parameters together with the corresponding estimated cost of each technology and suitability for different reuse purposes. 
Journal of Environmental Sciences (JES)

Faculty of Graduate Studies and Environmental Research, Ain Shams University

Mahmoud, et al.

Table(9): Comparison between different Oxidants.

\begin{tabular}{|c|c|c|c|c|c|}
\hline Oxidant & $\begin{array}{l}\text { Optimum } \\
\text { conditions }\end{array}$ & \multicolumn{2}{|c|}{ Achieved removal } & $\begin{array}{c}\text { Suitability for } \\
\text { reuse } \\
\text { purposes } \\
\end{array}$ & $\begin{array}{c}\text { Cost } \\
\text { estimation }\end{array}$ \\
\hline \multirow{5}{*}{$\begin{array}{l}\text { Hydrogen } \\
\text { peroxide }\end{array}$} & \multirow{5}{*}{$\begin{array}{cc}\text { - } & \text { Dose : } 15 \\
\text { mg/l } \\
\text { - } & \text { Stirring rate: } \\
& 40 \mathrm{RPM} \\
\text { - } & \text { Stirring time: } \\
& 30 \mathrm{~min}\end{array}$} & TSS (mg/l) & 5 & \multirow{5}{*}{$\begin{array}{c}\text { Class A } \\
\text { Class B } \\
\text { Class C } \\
\text { Class D } \\
\text { Law 48/1982 }\end{array}$} & \multirow{5}{*}{$\begin{array}{c}0.051 \\
\mathrm{USD} / \mathrm{m} 3\end{array}$} \\
\hline & & COD (mg/l) & 12 & & \\
\hline & & BOD5 (mg/l) & 2 & & \\
\hline & & TOC (mg/l) & 5 & & \\
\hline & & $\mathrm{TC}(\mathrm{CFU} / 100 \mathrm{ml})$ & 15 & & \\
\hline & - Dose: 10 & TSS (mg/l) & 1 & & \\
\hline & mg/l (FeSO4) & $\mathrm{COD}(\mathrm{mg} / \mathrm{l})$ & 5 & Class B & \\
\hline & $+15 \mathrm{mg} / \mathrm{l}$ & BOD5 (mg/l) & 0 & Class C & \\
\hline Fenton & $\begin{array}{c}\mathrm{H} 2 \mathrm{O} 2 \\
\text { Stiring rate. }\end{array}$ & TOC (mg/l) & 1 & Class D & $\begin{array}{c}0.085 \\
U S D / m 3\end{array}$ \\
\hline & $\begin{array}{c}40 \mathrm{rpm} \\
\text { - } \quad \text { Stirring time: } \\
30 \mathrm{~min} \\
\end{array}$ & TC (CFU/100ml) & 5 & $\begin{array}{c}\text { Law 48/1982 } \\
\text { (Nearly fresh } \\
\text { water) }\end{array}$ & \\
\hline & & TSS (mg/l) & 0 & & \\
\hline & - Dose: 10 & COD (mg/l) & 0 & & \\
\hline & & $\mathrm{BOD}_{5}(\mathrm{mg} / \mathrm{l})$ & 0 & Class A & \\
\hline & $\begin{array}{r}\mathrm{H} 2 \mathrm{O} 2+\mathrm{UV} \\
189 \mathrm{~nm} \text { and }\end{array}$ & TOC (mg/l) & 0 & $\begin{array}{l}\text { Class B } \\
\text { Class C }\end{array}$ & \\
\hline $\begin{array}{l}\text { Pnoto- } \\
\text { Fenton }\end{array}$ & $\begin{array}{c}\text { power of } 6 \\
\text { watts, }\end{array}$ & $\mathrm{TC}(\mathrm{CFU} / 100 \mathrm{ml})$ & 0 & $\begin{array}{c}\text { Class D } \\
\text { Law 48/1982 }\end{array}$ & $\mathrm{USD} / \mathrm{m} 3$ \\
\hline & - $\quad$ Stirring rate: & $\mathrm{COD}(\mathrm{mg} / \mathrm{l})$ & 8 & $\begin{array}{l}\text { (better than } \\
\text { fresh water) }\end{array}$ & \\
\hline & - Stirring time: & $\mathrm{BOD}_{5}(\mathrm{mg} / \mathrm{l})$ & 3 & & \\
\hline & $30 \mathrm{~min}$ & TOC $(\mathrm{mg} / \mathrm{l})$ & 4 & & \\
\hline & & TC (CFU/100ml) & 2 & & \\
\hline
\end{tabular}

TSS: Total Suspended Solids, BOD5: Biochemical Oxygen Demand, COD:

Chemical Oxygen Demand, TOC: Total Organic Carbon, TC: Total Coliform 
From Table (9), it's clear that all the used oxidants (hydrogen peroxide, Fenton and Photo-Fenton) have accomplished the required removal to allow the water to be reused for each required purpose. However, the cost benefit of using hydrogen peroxide is more favorable as it cheaper. Further comparison between the scaleup option, hydrogen peroxide could be more applicable to be scaled up and moreover, it could be nationalized as a strategic industry.

The results of each of the oxidants allow the reuse of each of them in different uses of water. This will increase the economic value of the water and its availability. The challenge of the water scarcity in Egypt pushes in the way for searching of alternative sources for water resources. Keeping with the water strategy of Egypt water reuse represents one of the potential solutions for such challenge. The Wastewater Quality Index and cost comparison is illustrated graphically at figure 9.

WWQI: Wastewater Quality Index, Cost: Cost comparison of different oxidation process

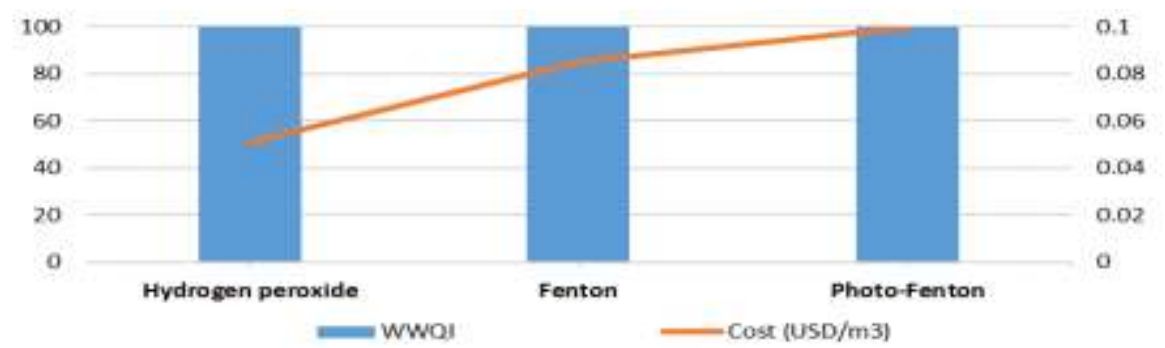

Figure (9): Wastewater Quality Index and cost comparison of different oxidation processes 
Journal of Environmental Sciences (JES)

Faculty of Graduate Studies and Environmental Research, Ain Shams University

Mahmoud, et al.

\section{CONCLUSION}

Based on the current water demand and resources in Egypt, the situation represent criticality for decision makers. Strategic direction for searching for alternative is becoming a must. Wastewater reuse represent a potential source for a round 8 Billion Cubic Meters (BCM) /year. The micropollutant and the sophisticated specification hinder the usage of wastewater. Advanced oxidation process represents new potential way for improving the effluent of Wastewater Treatment Plants (WWTPs). Through this study three WWTPs were investigated (Arab-Abosaaed, El Berka and Balaqs. The investigation illustrated that El Berka WWTP is the most vulnerable Wastewater Treatment Plant this why its effluent was used to conduct further treatment on it. Wastewater Quality Index (WWQI) For the effluent (output) of the three WWTPs indicated that mostly the three are appropriate for use according to Egyptian law 48/1982, Class D and Class C code 501/2015 specification. However, El Berka showed lower quality. This could be owed to bad input water quality. Effluent from the three-treatment plant is unsuitable for uses according to Class A and B code 501/2015. This hinders the use of water in the production of higher-value agricultural goods. All the oxidants used has been successfully implemented to achieve $100 \%$ WWQI for different reuse purposes. However, the cost benefit of using hydrogen peroxide is more favorable as it cheaper. Further comparison between the scaleup option, hydrogen peroxide is more 
applicable to be scaled up and moreover, it could be nationalized as a strategic industry.

\section{REFERENCES}

Abd Ellah, R. G.: Water resources in Egypt and their challenges, Lake Nasser casestudy. The Egyptian Journal of Aquatic Research, 46(1), 1-12,. (2020).

AbuZeid, K. M. (2020): Existing and Recommended Water Policies in Egypt. In Water Policies in MENA Countries (pp. 47-62). Springer, Cham.

Ameta, S. C., \& Ameta, R. (Eds.). (2018): Advanced oxidation processes for wastewater treatment: emerging green chemical technology. Academic press.

Asano, T., \& Tchobanoglous, G. (1987): Municipal wastewater treatment and effluent utilization for irrigation. Land and Water Development Division, FAO, Rome.

Bengtsson, L. (2010): The global atmospheric water cycle. Environmental Research Letters, 5(2), 025202.

Benveniste, J., \& Berry, P. (2004): Monitoring river and lake levels from space. ESA bulletin, 117, 36-42.

Bilgin, A. (2018): Evaluation of surface water quality by using Canadian Council of Ministers of the Environment Water Quality Index (CCME WQI) method and discriminant analysis method: a case study Coruh River Basin. Environmental monitoring and assessment, 190(9), 1-11.

Change, I. P. O. C. (2007): Summary for policymakers. Climate change, 118.

Cheremisinoff, P. N. (2019): Handbook of water and wastewater treatment technology. Routledge.

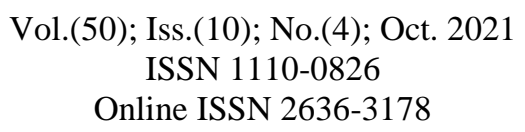


Collivignarelli, M. C., Pedrazzani, R., Sorlini, S., Abbà, A., \& Bertanza, G. (2017): $\mathrm{H}_{2} \mathrm{O}_{2}$ based oxidation processes for the treatment of real high strength aqueous wastes. Sustainability, 9(2), 244.

ECP 501 - 2015 Egyptian code 501/2015 for the use of treated wastewater in agriculture,

Ferrari, E., McDonald, S., Osman, R., (2014): Water scarcity and irrigation efficiency in Egypt. 17th annual conference on global economic analysis, "new challenges in food policy. Trade and economic vulnerability". June 18-20. Dakar, 28p

Gleick, P. H. (1993): Water in crisis. Pacific Institute for Studies in Dev., Environment \& Security. Stockholm Env. Institute, Oxford Univ. Press. 473p, 9, 1051-0761.

Harrison, E. Z., Oakes, S. R., Hysell, M., \& Hay, A. (2006): Organic chemicals in sewage sludges. Science of the total environment, 367(2-3), 481-497.

JUANICO, M. (1993): Alternative schemes for municipal sewage treatment and disposal in industrialized countries: Israel as a case study. Ecological Engineering, V2, pp. 101-118

Karimi, B., Ehrampoush, M. H., Ebrahimi, A., Mokhtari, M., \& Amin, M. M.: Catalytic oxidation of hydrogen peroxide and the adsorption combinatory process in leachate waste pretreatment from composting factory. International Journal of Environmental Health Engineering, 1(1), 15., (2012).

Koutsoyiannis, D. (2011): Scale of water resources development and sustainability: small is beautiful, large is great. Hydrological Sciences Journal, 56(4), 553-575.

Ksibi, M. (2006): Chemical oxidation with hydrogen peroxide for domestic wastewater treatment. Chemical Engineering Journal, 119(2-3), 161-165.

MWRI, 2015. (Ministry of Water Resources and Irrigation). 
PATTERSON R. A. (2000): Wastewater Quality Relationships with Reuse Options, 3rd International Symposium on Wastewater Reclamation, Recycling and Reuse; France 3.-7. July 2000.

Rice E.W., Baird R.B., Eaton A.D., Standard Methods for the Examination of Water and Wastewater, 23rd Edition, American Public Health Association, American Water Works Association, Water Environment Federation, ISBN: 9780875532875, 2017.

Schuol, J., Abbaspour, K. C., Srinivasan, R., \& Yang, H. (2008): Estimation of freshwater availability in the West African sub-continent using the SWAT hydrologic model. Journal of hydrology, 352(1-2), 30-49.

Sircoulon, J. (1991): Climate Water and Development in Climate Change: Science Impacts and Policy \{éd. par J. Jâger \&H. L. Ferguson) (Proc. Second World Climate Conference), 242-252.

Theodore, M. G. (2009):.Package dewatering wastewater treatment method, U.S. Patent No. 7,563,372. Washington, DC: U.S. Patent and Trademark Office.

Tony, M. A., \& Bedri, Z. (2014): Experimental design of photo-Fenton reactions for the treatment of car wash wastewater effluents by response surface methodological analysis. Advances in Environmental Chemistry, 2014.

Xu, M., Wu, C., \& Zhou, Y. (2020): Advancements in the Fenton process for wastewater treatment. Advanced Oxidation Processes, 61.

Zaviska, F., Drogui, P., Mercier, G., and Blais, J. F. (2009): Proc'ed'es d'oxydation avanc'ee dans le traitement des eaux et des effluents industriels: Application 'a la d'egradation des polluants r'efractaires. Rev. Sci. Eau, 22(4), 535-564. 


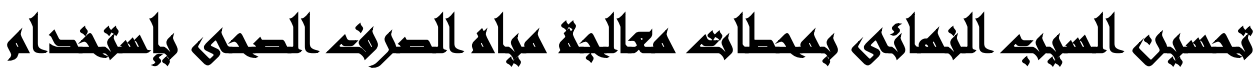

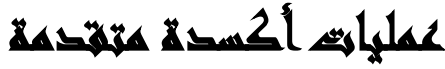

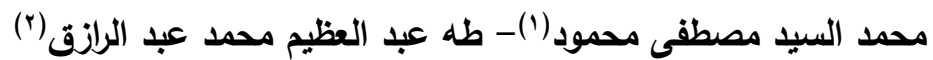

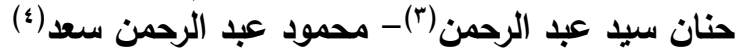

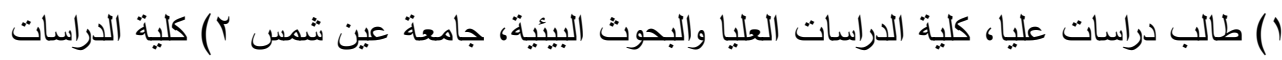

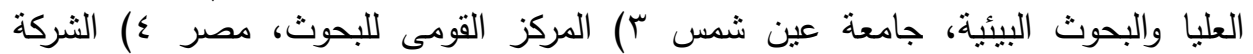

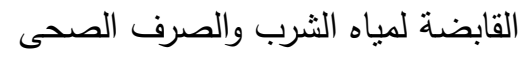

\section{ll}

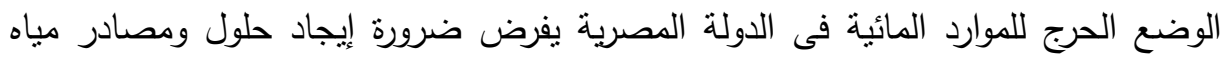

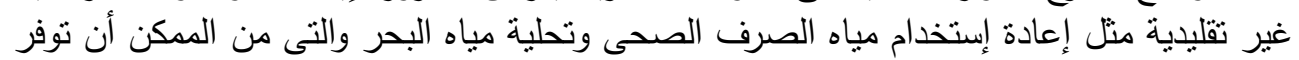

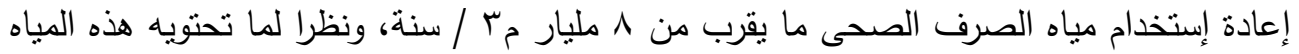

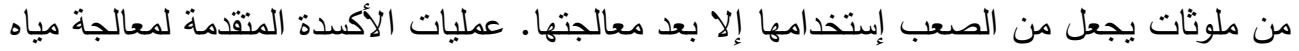

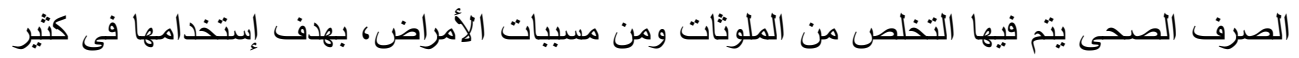

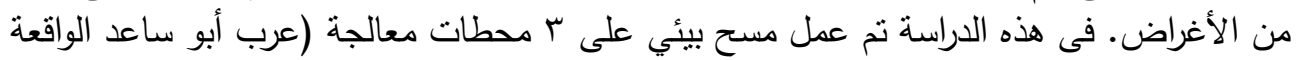

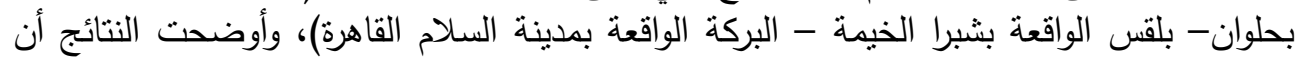

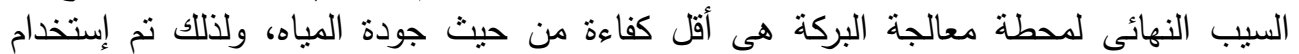

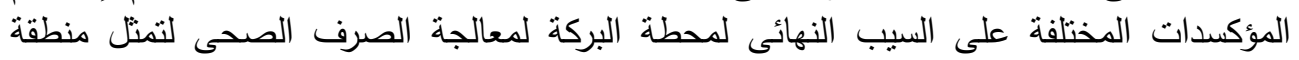

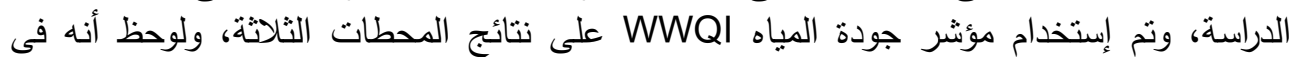

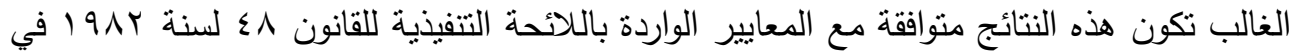

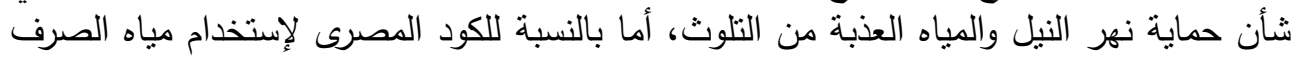

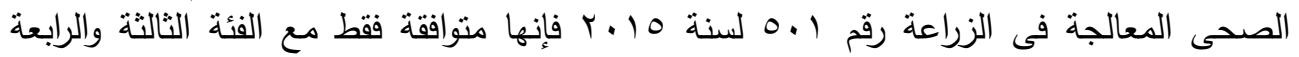

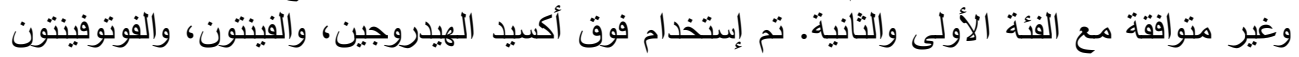

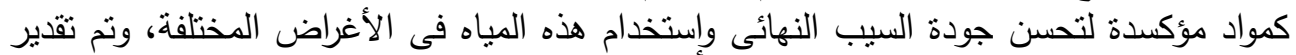

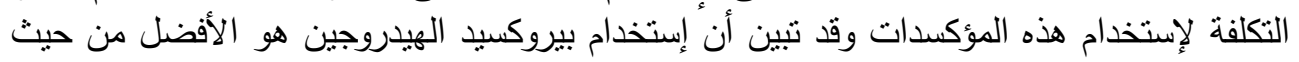

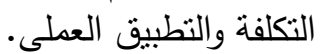
الكلمات المفتاحية: مياه الصرف الصحئ الصحى - مؤشر جودة مياه الصرف - إعادة الإستخدام الأكسدة - الفينتون الفناحية 